\title{
UTICAJ POROĐAJNE MASE I AKTUELNE TEŽINE DETETA NA NASTANAK PREVREMENOG PUBERTETA
}

\section{AUTORI}

Prof. dr Snežana Marković-Jovanović Medicinski fakultet Priština, Kosovska Mitrovica, Srbija

snezana.markovic.jovanovic@gmail.com

Snežana Marković-Jovanović ${ }^{1}$, Maja Ješić ${ }^{2}$, Vlada Bojić ${ }^{3}$, Aleksandar Jovanović ${ }^{2}$ Zorica Živković ${ }^{1}$, Andrijana Karanović ${ }^{\text {, Vera Zdravković }}{ }^{2}$

${ }^{1}$ Medicinski fakultet Priština /K. Mitrovica

${ }^{2}$ Medicinski fakultet Beograd

${ }^{3}$ Univerzitetska Dečija klinika, Beograd

\section{SAŽETAK}

Pubertet je razvojni period deteta praćen intenzivnim rastom i sticanjem reproduktivne sposobnosti. Na početak puberteta utiču mnogobrojni činioci: genetski faktori, neuropeptiidi i glikoproteini, gonadotropini, polni hormoni kao i ishrana deteta. Prevremeni pubertet se definiše kao pojava sekundarnih seksualnih karakteristika kod devojčica pre navršene 8-e, a kod dečaka pre 9-e godine života.

Poremećaji ishranjenosti nastali unosom hiperkalorijske hrane uvode dete u gojaznost koja je praćena preranim polnim sazrevanjem. S druge strane, stanja smanjene uhranjenosti deteta mogu biti praćene odloženim, odnosno zakasnelim pubertetom.

Cilj rada je da analiziramo publikovane rezultate o značaju i uticaju faktora kao što su porođajna masa, aktuelna težina i BMI na nastanak preuranjene pulne zrelosti

Prema rezultatima ove studije, deca sa izraženijim manifestacijama prevremenog puberteta imala su značajno nižu porođajnu masu

Diskusije: Deca sa porođajnom masom manjom od 2500g, kao i deca rođena kao SGA novorođenčad (“mali prema gestacionoj starosti" - small for gestational age), direktno su povezani sa ranijim pubertalnim sazrevanjem. Frich i sar.su pre pet decenija utvrdili da dostizanje telesne težine od 48 kg kod devojčica predstavlja "kritičnu masu” za pojavu menarhe

Zaključak: Pojava sekundarnih seksualnih karakteristika češća je u dece sa povišenom telesnom težinom a obrnuto je povezana sa vrednostmai porođajne mase deteta

Ključne reči: pubertet, prevremeni pubertet, ishrana, BMI, porođajna masa

\section{ENGLISH}

\section{SUMMARY}

Introduction: Puberty is a juvenile developmental period accompanied by intensive growth and acquisition of reproductive ability. The onset of puberty is influenced by many factors: genetics, neuropeptides and glycoproteins, gonadotropins, sex hormones and the child's nutrition status. Premature puberty is defined as the appearance of secondary sexual characteristics in girls before the age of 8 , and in boys before the age of 9 .

The aim of this paper is to analyze the published results on the importance and influence of factors such as birth weight, current weight and BMI on the development of premature puberty.

Results: Eating disorders caused by eating high-calorie foods lead a child to obesity, which is accompanied by premature puberty. On the other hand, conditions characterized by reduced nutrition may be accompanied by delayed puberty. According to the results of this study, children with more pronounced manifestations of precocious puberty had a significantly lower birth weight

Discussion: Birth weight of less than $2500 \mathrm{~g}$, as well as newborns' SGA (small for gestational age), are directly related to earlier pubertal maturation. Five decades ago, Frich et al found that reaching a body weight of $48 \mathrm{~kg}$ in girls is a "critical mass" for development of menarche.

Conclusion: The occurrence of secondary sexual characteristics is more frequent in children with increased body weight and correlates inversely with the child's birthweight.

Key words: puberty, precocious puberty, diet, additives, hormonal supplementsand WC were below the values of the cross- 


\section{UVOD}

Pubertet je životno doba tokom koga se dešava polno sazrevanje; povezan je sa složenim anatomskim i funkcionalnim promenama koje omogućavaju sticanje sposobnost za reprodukciju. Pubertetski razvoj uključuje rast i sazrevanje primarnih polnih odlika i pojavu sekundarnih polnih karakteristika (1). To je period fizičkog i psihosocijalnog razvoja.

Većina devojčica ulazi u pubertet u uzrastu od 8 do 15 godine, a dečaci između 10 i 15 godine sa maksimumom pubertetstog razvoja u 13-oj godini (2). Prevremeni pubertet se definiše kao razvoj dojke (B2, Tanner) pre navršene 8-e godine života kod devojčica i/ili početak pubične maljavosti pre 9-e godine kod dečaka, odnosno pojava menarhe pre 10-e godine starosti devojčice.

Etiološka klasičikacija ovog porećaja obuhvata: gonadotropin zavisni,odnosno centralni (kompletni ili pravi) pubertet, gonadotropin nezavisni pubertet i nekompletni prevremeni polni razvoj. Klinički prevremeni pubertet može bit iziseksualan ili heteroseksualan.

Centralni prevremeni pubertet (CPP) je najčešći oblik pravog pubertetsog sazrevanja deteta. Incidenca CPP u detinjstvu je 1 na 5000 dece i deset puta je učestaliji kod devojčica. Ovaj poremećaj nastaje ranom aktivaciojom hipotalamusno-hipofizno-gonadne osovine; u skladu je sa hromozomskim i gonadnim polom jedinke a po kliničkoj slici odgovara fiziološkom pubertetu (rast dojki, pubična maljavost, porast volumena testisa, intenzivni rast u visinu, ubrzano koštano sazrevanje).

Izolovana prevremena telarha (telarcha praecox) i pubarha (pubarche praecox) se definišu kao rani nezavisni porast dojki, odnosno nastanak pubične maljavosti, u odsustvu drugih znakova prevremenog pubereta (npr. ubrzanje rastenja, koštanog sazrevanja, promene u veličini uterusa i vaginalnoj sluzokoži) kod ženske dece pre osme godine života, a kod dečaka pre devete godine.

\section{CILJ RADA}

1. Utvrditi učestalost nastanka prevremenog puberte-ta, odnosno parcijalnog puberteta prema porođajnj masi i gestacionoj starosti deteta

2. Analizirati antropometrijske $\mathrm{i}$ hormonalne parametre kod dece sa centralnim pubertetom i primenjenom hormonalnom terapijom gonadotropin rilizing hormonom $(\mathrm{GnRH})$ i dece sa izolovanim znacima prevrmenog puberteta (prevremena telarha i pubarha)

\section{MATERIJAL I METODE}

Istraživanje predstavlja retrospektivnu kliničku studiju kojom je obuhvaćeno 75-oro dece, uzrasta od navršene 5-e do 9-e godine života, koja su kontrolisana u endokrinološkoj ambulanti ili hospitalizovana na endokrinološkom odeljenju Univerzitetske Dečije klinike u Beogradu, zbog ispoljenog jednog ili više znaka pubertetskog razvoja a u periodu od 2013 do kraja 2019. god.

Osnovni kriterijumi za uključivanje dece u istraživanje bio je rana pojava sekundarnih seksualnih karakteristika; devočice kod kojih su znaci polne zrelosti primećeni u uzrastu od šeste godine do 8-e godine, odnosno dečaci sa prevremenim polnim razvoje, u uzrastu 6-e do 9-e godine.
Prvu ispitivana grupu dece činio je skup devojčica i dečaka, njih 35 , koja su na osnovu antropometrijskih karakteristika, hormonskog testiranja (nivoa gonadotropina, estradiola I testosterona,), radioloških analiza (RTG leve šake, EHO male karlice i NMR endokranijuma) kao i GnRH testiranja definisana kao grupa sa centralnim prevremenim pubertetom.

Drugu ispitivanu grupu su činila deca (35-oro), kod kojih je posle primenjenog protokola ispitivanja prevremenog puberteta, utvrđeno da ne postoji aktivacija osovine hipotalamus-hipofiza-gonade, odnosno, postavljena je dijagnoza izolovanog parcijalnog prevremenog puberteta (PPP).

Od anamnestičkih podataka dobijenih od roditelja dece, od značaja nam je bio podatak o porođajnoj masi deteta kao i gestacionoj nedelji kada se desio porođaj.

Od podataka iz kliničkog pregleda deteta, relevantni su nam bili telesna visina (TV), telesna masa (TM) deteta, znaci pubertetskih promena i vreme njihovog javljanja. Na osnovu ovih antropometrijskih podataka deteta, određen je pripadajući percentil na percentilnim krivuljama prema polu, izračunat je Indeks telesne mase (ITM) kao i SD, odnosno odstupanje od medijane. ITM je izračunat po formuli: ITM=TT $(\mathrm{kg}) / \mathrm{TV} 2\left(\mathrm{~m}^{2}\right)$.

Koncentracija gonadotropina u serumu merena je metodom radioimunoesej (RIA).

U statističkoj obradi podataka korišćen je Studentov Ttest za male nezavisne uzorke i x2 test. Za procenu normalnosti distribucije, korišćeni su testovi Kolmogorov-Smirnova $i$ Shapiro-Wilk. U okviru deskriptivne statistike koriščeni su: srednja vrednost, standardna devijacija (SD) i procentualna distribucija.

\section{REZULTATI}

Ovim istraživanjem obuhvaćeno je 75-oro dece uzrasta 6-9 godina, koji su zbog ispoljenih znakova prevremene polne zrelosti pregledani ili lečeni na Univerzitetskoj Dečijoj klinici u Beogradu.

Tabela 1. Opšte karakteristike ispitanika

\begin{tabular}{|c|c|}
\hline Usrast pri pryumu preglealu (golline) & $7.35=1.35$ \\
\hline Telesma maxa ibgl & $32.73-9.31$ \\
\hline Telesmu vasinu (m) & $1.33: 4.12$ \\
\hline 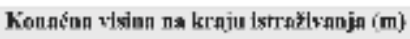 & $144.55-11.49$ \\
\hline Indeks telosme mase (kgim2) & $17,89=\hat{j}, 006$ \\
\hline Ciljna visina $\langle\mathrm{ml}\rangle$ & $167.0 \mathrm{~J}=6.34$ \\
\hline Purcodajnu masu $(y)$ & 3122.66 । $305.9 \mathrm{~g}$ \\
\hline
\end{tabular}

U tabeli 1 su prikazane opšte karakteristike sve dece unutar istraživačkih grupa. Pa je tako, prosečna starost dece unutar našeg istraživanja iznosila $7.35 \pm 1.35$ god.; dominantno su bile zastupljene devojčice, odnosno činile su $96 \%$ svih ispitanika (ukupno njih, 73-i). Srednja vrednost telesne mase je $32,33 \pm 9.31 \mathrm{~kg}$, a prosečna visina je bila $1.33 \pm 0.12 \mathrm{~m}$. Na kraju istraživačkog perioda i praćenja visine dece, srednja visina je iznosila $144.65 \pm 11.93 \mathrm{~m}$. Prosečno određen Indeks telesne mase (ITM) na prvom merenju dece, bio je $17.89 \pm 3.00 \mathrm{~kg} / \mathrm{m}^{2}$. Srednja vrednost genetskog potencijala (ciljne visine) dece iznosio je $167.00 \pm 6.94 \mathrm{~m}$, a njihova prosečna porođajna težina bila je 3022.66 + 805.98g. 
Dijagram 1. Raspodela ispitanika prema uzrastu

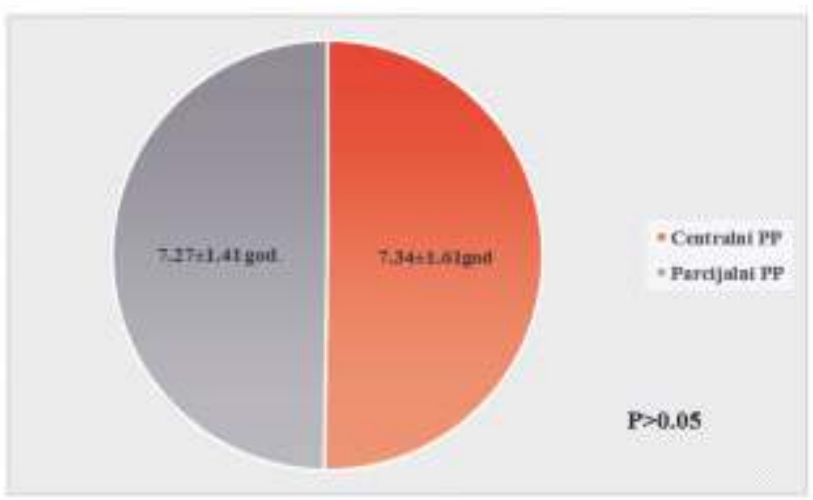

Prema uzrastnoj dobi, između ispitanika u grupi sa Centralnim prevremenim pubertetom grupom sa parcijalnim izolovanim oblicima prevremenog puberteta, (PPP) nije postojala statistički značajna razlika. $U$ grupi dece na terepiji, prosečna starost bila je $7.34 \pm 1.61$ godinu, a u grupi dece sa PPP prosečna starost je bila $7.27 \pm 1.41$ godinu.

Tabela 2. Raspodela ispitanika prema vrednosti ITM

\begin{tabular}{|c|c|c|}
\hline $\begin{array}{l}\mathrm{ki}-1.75 \\
p-0.11\end{array}$ & $\begin{array}{l}\text { Centrulni prevremeni paibertet } \\
\text { (CPP) } \% \text { \% }\end{array}$ & 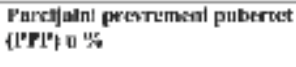 \\
\hline $10.5-50$ & 4 & 5.56 \\
\hline$P^{2}(50-75)$ & 20 & 27.78 \\
\hline$P(55.96)$ & 40 & 25 \\
\hline $\mathrm{P}(90-95)$ & 20 & 22.22 \\
\hline$P=47$ & 16 & 19.44 \\
\hline
\end{tabular}

Prateći distribuciju ispitanika prema dobijenim vrednostima ITM, nije nađena statistička značajnost između grupa. Uočljivo je da četvrtina dece sa CPP se nalazi u grupi koja je u riziku za nastanak gojaznosti (predgojaznost), odnosno njihov ITM je u rangu P90-P97, a 16\% ispitanika ima telesnu masu iznad P97. Takođe, i u grupi ispitanika sa PPP, $22.22 \%$ dece je imalo ITM iznad preporučenih granica normalne uhranjenosti deteta, a $19.44 \%$ njih, ima telesnu težinu prema svojoj TV iznad dozvoljenih pedijatrijskih normativa ( $P>97$ ). Interesantaan je podatak da ITM ispod medijane (P3P50) nalazimo kod svega $4 \%$ ispitanika sa Centralnim prevremenim puberteteom i u sličnom procentu kod dece sa Parcijalnim prevremenim pubertetom (5.56\%).

Dijagram 2. Srednja porođajna masa u dve ispitivane grupe

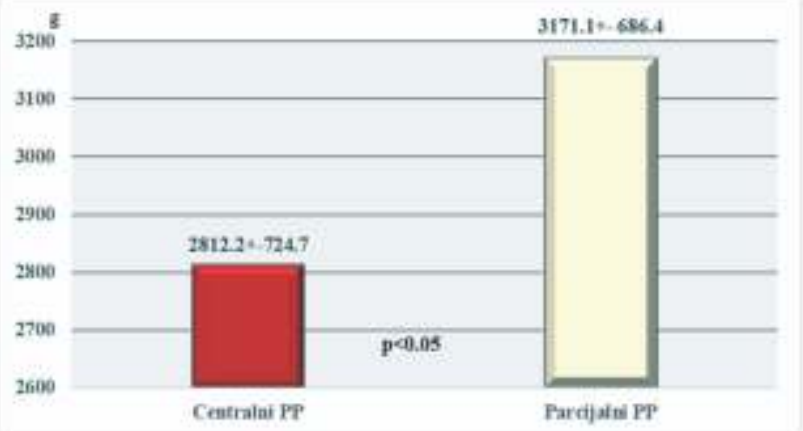

Prema rezultatima ove studije, deca sa izraženijim manifestacijama prevremenog puberteta imala su značajno nižu porođajnu masu $(2812.2 \pm 724.7 \mathrm{~g}$ u grupi ispitanika sa centralnim PP, koji su bili na terapiji diferelinom, naspram $3171 \pm 686.4 \mathrm{~g}$ u kontrolnoj grupi). Međutim, potrebno je dalje istraživanje da bi se utvrdilo da li je ova veza direktno uzročno-posledična.

Dijagram 3. FSH i LH u prvom, drugom i trećem merenju

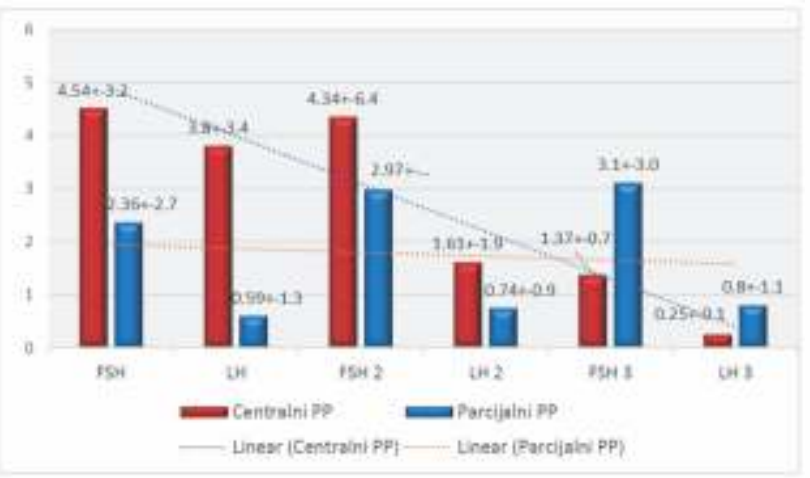

Na dijagramu 3 je jasno uočljivo postepeno sniženje sekrecije FSH i LH na pretpubertetske nivoe pod uticajem permanentne terapije diferelinom (naznačeno plavom linijom trenda i odgovarajućim stubičastim dijagramima crvene boje), sa početnih srednjih vrednosti $4.54 \pm 3.2$ na $0.25 \pm 0.1$ na kraju kraju ovog perioda; za razliku od toga, u grupi ispitanika koji nisu primali terapiju, nivoi ovih hormona su bili relativno konstantni (narandžasta linija trenda, odnosno narandžasti stubičasti dijagrami). Uočava se i statistički značajna razlika $(p<0.05)$ u nivou gonadotropina u bazičnom merenju između dve grupe ispitanika $(4.54 \pm 3.2$ naspram $2.36 \pm 2.7 \mathrm{IU} / \mathrm{L}$ za FSH, odnosno $3.8 \pm 3.4$ prema $0.59 \pm 1.3 \mathrm{za}$ LH), koja je i bila bitan činilac u odluci da se kod te dece započne medikamentozna terapija sa ciljem da se odloži prevremeni pubertet.

Dijagram 4. Prosečne vrednosti estradiola u dve ispitivane grupe u prvom, drugom i trećem merenju

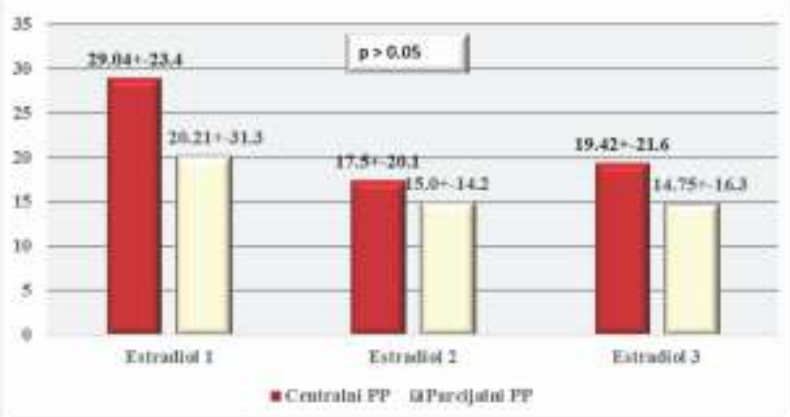

Premda su nivoi estradiola nominalno bili nešto viši kod ispitanika sa centralnim PP $(29.04 \pm 23.4 \mathrm{pmol} / \mathrm{L}$ prema $20.21 \pm 31.3 \mathrm{pmol} / \mathrm{L} u$ grupi sa parcijalnim PP, u prvom merenju, zatim , $17.5 \pm 20.1$ naspram $15.0 \pm 14.2$ u drugom $i$ $19.42 \pm 21.6$, odnosno $14.75 \pm 16.3$ u trećem merenju) statističkim testiranjem nije utvrdjena značajna razlika izmedju 2 grupe ni u jednom od 3 merenja ( $p>0.05$ ). Slični rezultati su dobijeni testiranjem nivoa testosterona. 


\section{DISKUSIJA}

Centralni prevremeni pubertet (CPP) nastaje usled ranog sazrevanja osovine hipotalamus- hipofiza -gonade (HPG). Poremećaj se češće javlja kod devojčica u odnosu na dečake, promera 3:1 do 23:1. Pored svih ispitivanja, anketiranja i testiranja, najčešći uzrok prerane seksualnosti kod devojčica je idiopatski (3). Nasuprot tome, centralni prevremeni pubertet izazvan organskim faktorima se češće javlja kod dečaka. Gojazost u ranom detinjstu, usporen intrauterini razvoj deteta, gojaznost roditelja i prisutnost šećerne bolesti su faktori rizika povezani sa ranom telarhom. S obzirom da se parcijalni prevremeni pubertet karakteriše ranim razvojem dojki ili pubičnom maljavošću, teško je na samom početku polnih naznaka diferencirati centralni prevremeni pubertet od parcijalnih oblika polnog sazrevanja. Mnogobrojne studije su ispitivale povezanost između fetalnog razvoja, male porođajne težine $(<2500 \mathrm{~g})$ i nastanka puberta. SGA (small for gestational age, mali za uzrast,) reprezentuje grupu dece čija je težina ili dužina tela manja od očekivane prema gestacionoj starosti i polu deteta. Jedan od mogućih mehanizama (4), odgovornih za pojavu prevremenog puberteta kod hipotrofične odojčadi i/ili SGA, je akumulacija visceralnog masnog tkiva u ranom detinjstvu, uslovljavajući insulinsku rezistenciju i hiperinsulinizam koji ima ključnu ulogu u razvoju hiperandrogenizma. Porast nivoa adiponektina, IGFBP-1 i triglicerida u uzrastu ekpanzivnog rasta ove dece između 2-4 godine života, uzrokuju glukoznu intoleranciju i recipročno, insulinsku rezistenciju. Prema poznatoj studiji (5) Avon Longitudinal Study of Parents and Children (ALSPAC), kombinacija male porođajne mase i ubrzanje postnatalnog prirasta u težini uzrokuje porast totalne i centralne adipoznosti, sa posledičnim skokom koncentracije IGF-1 oko 5-e godine a snižavanje insulinske senzitivnosti u 8-oj godini (6).

Prema rezultatima naše studije, deca kod kojih je postavljena indikacija za prekid pubertetskog razvoja i primenu agonista $\mathrm{GnRH}$, imala su značajno nižu porođajnu masu (2812. $2 \mathrm{~g} \pm 724.7 \mathrm{~g}$, u odnosu na kontrolnu grupu dece kod kojih je prosečna porođajna masa bila $3171 \mathrm{~g} \pm 686.4 \mathrm{~g}$ ).

Ispitivanja pokazuju da se prevremena pubarha javlja kod čak 35\% dece rođenih kao SGA. Naime, kod ove dece postoji fetalna adrenalna hipoplazija s niskim nivoima dehidroepiandrosterona (DHEA). Nakon rođenja, a pogotovo u one dece koja naprave rani i izdašni fenomen "catch-up growth", akceleracija u produkciji adrenalnih androgena postaje izražena, time i šansa za rano razvijanje pubarhe kod deteta i sindroma policističnih jajnika kod devojčica. Dečaci rođeni sa malom porođajnom težinom imaju visok nivo folikula-stimulišućeg hormona (FSH) i nizak nivo inhibina $B$ kao i volumen testisa tokom adolescencije. Kod devojčica rođenih kao SGA, pored ranije telerhe i pojava menarhe je uznapredovala, za oko 5-10 meseci u odnosu na populaciju devojčica rođenih sa prosečnom telesnom masom. Otkriveno je da je kod njih stopa ovulacije smanjena, a primenjene terapijske mere za smanjenje insulinske rezistencije, povećavaju indeks ovulacije (7).

Tokom puberteta, dešavaju se promene u građi tela $i$ proteinskom metabolizmu, pod uticajem nekoliko hormonskih mehanizama. Pubertetski skok u telesnom rastu nastaje sinergističkim dejstvom povećane sekrecije gonadalnih polnih hormona (pre svega testosterona), porastom somatotropnog hormona, IGF-1 i povećanom koncentracijom insulina. Tokom puberteta, slobodni insulin, IGF-1 I IGFBP-3 koreli- šu pozitivno sa retencijom leucina, smanjuju leucinsku oksidaciju i omogućavaju proteinsku iskoristljivost. IGF-1 usporava enegergetski gubitak i štedi belančevine.

Pretpostavlja se da i hormon leptin ima izuzetno značajnu ulogu u povezanosti između telesne masti (gojaznost) i ranijeg puberteta. Povećana koncentracija leptina u gojazne dece ima ulogu u regulaciji apetita kao i u nastanku puberteta i uspostavljanju reproduktivnih funkcija. Ovu ulogu, leptin ostvaruje STAT-3 mehanizmom. STAT-3 gen je deo familije STAT gena koji su neophodni za sintezu proteina unutar ćelija. Leptin direktno stimuliše oslobađanje $\mathrm{GnRH}$, odnosno gonadotropina, te se na taj način uspostavlja dobro poznata uzročno-posledična veza porasta telesne mase i nastanka puberteta. Evidentna je i polna dihotomija u produkciji leptina - sa jednakom količinom masnog tkiva žene imaju više leptina od muškaraca, budući da testosteron povratno inhibira produkciju leptina, a estrogeni ne. Stoga nivo leptina raste u pubertetu devojčica sve vreme, dok u dečaka nakon stadijuma 3 po Turrneru pod dejstvom testosterona počinje da pada i takav ostaje i kod odraslih muškaraca $(8,9)$. Poremećaji ishrane kao anorexia neurose i bulimija, malapsorpcioni sindromi i/ili hronične bolesti creva mogu dovesti do zakasnelog puberteta.

Shodno tome, GnRH stimuliše sekreciju LH i FSH iz hipofize, što zauzvrat stimuliše gonade koje luče testosterone $i$ estradiol. (10)

I pojava menarche, kod devojčica definisana je postizanjem određene telesne mase. Naime, Frisch I Revell su izneli teoriju da je nastanak menstrualnih cuklusa povezan sa sadržajem telesne masti u telu devojčica, odnosno dostizanje telesne težine od $48 \mathrm{~kg}$ smatra se kritičnom za prvo menstrualno krvarenje. (11).

U fiziološkom pubertetu, kod devojčica se kao prvi znak uočava rast dojki uslovljen povećanom sekrecijom estrogena. Ali, estrogeni koji uslovljavaju razvoj grudi ne moraju biti odraz povećane ovarijalne aktivnosti. Naime, masno tkivo sadrži aromatazu koja može da stvara estrogene iz andogenih prekursora (androstendiona). Iz tog razloga, često postoji dijagnostička dilema etiologije rasta dojki kod devojčica; da li porast nastaje kao posledica hormonske aktivnosti (u centralnom prevreenom pubertetu) ili je reč o izolovanoj telarhi, kao rezultat ekstraglandularno povećane koncentracije estrogena i veće količine masnog tkiva unutar dojke (12).

Prateći preporuke Američkog vodiča pravilne ishrane iz 2010. godine $(13,14,15)$, devojčicama uzrastne grupe od 9 do 13 godina, za pravilan rast i razvoj, potrebno je 1400 do 2200 kalorija a u uzrastu 14 do 18 godina 1800 do 2400 kalorija dnevno. Dečacima starosti 9-13 godina za sveoje dnevne potrebne sa minimalnom fizičkom aktivnožću utroše 1600 do 2600 kalorija, a u uzrastu 14 do 18 godine broj potrebnih dnevnih kalorija iznosi 2000 do 3200 . Za devojčice i dečake koji su fizički intenzivno aktivni broj dnevno potrebnih kalorija može biti i 5000 .

Peripubertetska gojaznost kod devojčica je u korelaciji sa hiperandrogenemijom... Primećeno je da postoji značajno veći porast DHEA-S tokom godine kada je dete imalo najveći porast BMI u poređenju sa godinom kada je porast BMI niži (16). Ovo sugeriše da povec anje telesne masti može igrati kritičnu ulogu u uključivanju izlučivanja adrenalnih androgena $i$ adrenarhe. Studija grupe franscuskih istraživača, otkrila je da $32,5 \%$ devojčica sa pojavom pubične maljavosti između 4 i 8 godina ima BMI> 2SD u odnosu na normalne vrednostii da je korelacija između vrednosti BMI i seruma DHEA-S bila veoma značajna. 
U našim rezultatima, koncentracija FSH je u grupi dece sa centralnim pubertetom pri inicijalnom merenju, pokazala vrednosti od 4.54 $\pm 3.2 \mathrm{IU} / \mathrm{L}$. U drugom merenju (a kod najvećeg broja dece je to bilo tri meseca nakon započete terapije agonistima GnRH, nivo FSH je diskretno smanjen sa prosečnom koncentracijom 4.34 $\pm 6.43 .2 \mathrm{IU} / \mathrm{L}$, dok su niske, prepubertetske vrednosti postignute $\mathrm{u}$ drugom merenju, šest meseci po započetoj terpiji 1.37 $\pm 0.73 .2 \mathrm{IU} / \mathrm{L}$. S obzirom na sporo delovanje gonadotropin rilising hormona $(\mathrm{GnRH})$ na koncentracije gonadotropina u plazmi, opravdano je određivati koncentracije hoormona FSH i LH, nakon 5 ili 6 meseci, posle započete terapije. U našem istraživanju, u grupi dece sa parcijalnim znacima puberteta, koncentracije luteinizirajućeg hormona (LH), pri prvom, drugom i trećem merenju su bile uravnotežene sa tendencijom blagog povećanja

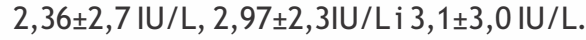

O malom dijagnostičkom značaju gonadotropina u serumu ukazuje više radova. Jedna od studija (17), navodi da srednja vrednost bazalnog gonadotropina u plazmi u stadijima puberteta 2, 3 i 5 je niža kod dece sa idiopatskim prevremenim pubertetom nego kod devojčica koje normalno sazrevaju. Takođe i vrednosti estrona i estradiola, pariraju koncentracijama ovih hormona kod deojčica bez znakova puberteta. Koristeći imunoesej metode treće generacije i bazairajući se na bazalne vrednosti luteinizirajućeg hormona, moguće je potvrditi aktivaciju osovine hipotalamus-hipofizagonade kod $>90 \%$ devojčica, ali ne kod svih, rezultat je istraživanja komparativne studije grupe autora (18).

$\mathrm{U}$ devojčica se nivo estradiola (E2), u serumu, ne koristi za dijagnozu CPP, s obzirom na njihovu nisku osetljivost i veliko preklapanje između normalne prepubertalne i pubertalne dece. U našem istraživanju, su nivoi estradiola nominalno bili nešto viši kod bolesnika na terapiji $(29.04 \pm 23.4$ $\mathrm{pmol} / \mathrm{L} \mathrm{u}$ ispitivanoj prema $20.21 \pm 31.3 \mathrm{pmol} / \mathrm{L}$ u kontrolnoj grupi u prvom merenju, zatim, $17.5 \pm 20.1 \mathrm{pmol} / \mathrm{L}$ naspram $15.0 \pm 14.2 \mathrm{pmol} / \mathrm{L}$ u drugom i $19.42 \pm 21.6 \mathrm{pmol} / \mathrm{L}$, odnosno $14.75 \pm 16.3 \mathrm{pmol} / \mathrm{L}$ u trećem merenju), pri čemu nije postojala statistički značajna razlika između ovih grupa u sva tri mereja. Iz ovoga sledi zaključak da koncentracije polnih hormona (estradiola), kako bazalne vrednosti, tako i njihove koncentracije u kasnim fazama puberteta nisu signifikantni i senzitivni parametri procene toka pubertetskog razvoja.
Za razliku od toga, kod dečaka je serumski ukupni testosteron osetljiv i realan parametar u dijagnozi preuranjenog puberteta (19), ali je samo njegovo određivanje nedovoljan pokazatelj u diferencijalnoj dijagnozi centralnog $i$ perifernog puberteta. Stoga se dijagnoza centralnog puberteta, oslanja na određivanje nivoa LH.

Nenormalno lučenje luteinizirajućeg hormona (LH), takođe može doprineti hiperandrogenemiji koja je povezana sa gojaznošću. LH je stimulans za proizvodnju androgena u teka ćelijama jajnika i ključni permisivni faktor hipendrogenemije u PCOS.

Prevremeni pubertet kod dece, pre svega kod devojčica je sve učestalji a poslednjih dve decenije, najčečće je posledica gojaznosti. Uticaj ishrane na nastanak ove pojave se bazira na kvatitataivnom (količinskom) efektu hrane, odnosno prekomernoj telesnoj težini i povećanom masnom tkivu koji aktivira intracelularne $i$ hormonske mehanizme. Poremećaji ishrane praćeni unosom male količine hrane/kalorija, kao anorexia nervosa i bulimija, malapsorpcioni sindromi i hronične bolesti creva mogu dovesti do zakasnelog puberteta.

\section{ZAKLJUČAK}

1. Deca sa centralnim prevremenim pubertetom, kod kojih je bio indikovan medikamentni tretman, imala su nižu porođajnu masu. Ovu povezanost je verovatno moguće objasniti mehanizmom insulinske rezistencije u periodu postpartalnog razvoja.

2. Prema rezultatima naše studije, velika većina ispitanika (dominantno devojčice) imale su ITM koji ih je svrstavao u grupu rizika za nastanak gojaznosti, ili u grupu gojaznih $(P>97)$. Pri tome, postoji ravnomerna distribucija u ITM u grupi dece sa CPP I indikovanom terapijom prekida pubertetskog razvoja, kao I u grupi dece koja su bila na klinićkom praćenju

3. Obezitet predstavlja krucijalni uzrok početka i manifestovanja kliničkih simptoma polne zrelosti (telarha, pubarha)

\section{LITERATURA}

1. Vlaški J., Katanić D., Fiziologija puberteta i poremećaja pubertetskog razvoja; Pedijatrija, Urednici Bogdanović R., Radlović N. ,2016; II; 1244-49

2. Sarah-Jayne Blakemore,Stephanie Burnett, and Ronald E Dahl The Role of Puberty in the Developing Adolescent Brain. Hum Brain Mapp. 2010; 31(6): 926-93, DOI: 10.1002/hbm.21052

3. Chittwar S, Shivprakash, and A. C. Ammini;Precocious puberty in girls; Indian J Endocrinol Metab. 2012 Dec; 16(Suppl 2): S188-S191

4. Sangita Yadav and D Rustogi Small for Gestational Age: Growth and Puberty Issues Indian Pediatr 2015;52: 135-140

5. Jaquet D, Deghmoun S, Chevenne D, Czernichow P, Levy-Marchal C. Low serum adiponectin levels in subjects born small for gestational age: impact on insulin sensitivity. Int J Obes. 2006; 30:83-7, doi: 10.1038/sj.ijo.0803106

6. Neville KA, Walker JL. Precocious pubarche is associated with SGA, prematurity, weight gain, and obesity. Arch Dis Child. 2005;90:258-61, DOI: 10.1136/adc.2004.053959.

7. Ashraf Soliman, Vincenzo De Sanctis and Rania Elalaily. Nutrition and pubertal development. Indian J Endocrinol Metab. 2014; 18(Suppl 1): S39-S47, DOI: 10.4103/2230-8210.145073

8. Buyken AE, Karaolis-Danckert N, Remer T. Association of prepubertal body composition in healthy girls and boys with the timing of early and late pubertal markers.Am J Clin Nutr. 2009 Jan; 89(1):221-30, DOI: 10.3945/ajcn.2008.26733 
9. Saša Živić, Vesna Ćirić, Sandra Stanković. Gojaznost i udružene bolesti u detinjstvu, Medicinski glasnik, vol. 15, 2010; 4758

10. Tatjana Novaković i Slavica Pajović, naslov - Endokrinologija, 251-259, 2010; ISBN 978-86-80601-39-7

11. Frich RE, Revelle R. Height and weight at menarche and a hypothesis of critical body weights and adolescent events. Science 169:397, 1970

12. Ahmed ML, Ong KK, Dunger DB. Childhood obesity and the timing of puberty. Trends Endocrinol Metab. 2009; 20(5):23 7-42 DOI: 10.1016/j.tem.2009.02.004 PMID: 19541497

13. Christine M. Burt Solorzano, Christopher R. McCartney.Obesity and the pubertal transition in girls and boys. doi: 10.1530/REP-10-0119

14. Van Weissenbruch MM, Engelbregt MJ, Veening MA, Delemarre-van de Waal HA. Fetal nutrition and timing of puberty. Endocr Dev. 2005;8:15-33, DOI: 10.1159/000084084

15. Hernández MI, Mericq V. Impact of being born small for gestational age on onset and progression of puberty. Best Pract Res Clin Endocrinol Metab. 2008; 22(3):463-76 DOI: 10.1016/j.beem.2008.02.003.

16. Reinehr T, de Sousa G, Roth CL, Andler W. Androgens before and after weight loss in obese children. J Clin Endocrinol Metab. 2005; 90(10):5588-95. DOI: 10.1210/jc.2005-0438

17. F. Bidlingmaier, Butenandt And d. Knorr Plasma Gonadotropins and Estrogens in Girls with Idiopathic Precocious Puberty Pediat. Res./ 1977, 1: 91-94

18. Houk CP. Kunselman A. et al Adequacy of a single unstimulated luteinizing hormone level to diagnose central precocious puberty in girls. Pediatrics. 2009. 123(6):e1059-63

19. Latronico AC, Brito VN, Carel JC. Causes, diagnosis, and treatment of central precocious puberty. Lancet Diabetes Endocrinol. 2016. Mar;4(3):265-274. doi: 10.1016/S2213-8587(15)00380-0 